\title{
HODNOTENIE INTENZITY LUDSKÉHO VPLYVU NA VYUŽÍVANIE KRAJINY A JEJ VÝVOJ: PRÍPADOVÁ ŠTÚDIA ENVIRONMENTÁLNE ZAŤAŽENEJ OBCE RUDŇANY
}

\author{
Matej Hruška, František Petrovič
}

\begin{abstract}
Understanding of the causes and consequences of land use/cover change (LUCC) is one of the prime goals of global change research. The vast majority of the LUCC in Slovenske rudohorie Mts is associated with the deposits of mineral resources that have resulted in an increase of the anthropogenic impact. These changes significantly affect the ecological landscape stability and cause its weakening. A coefficient of ecological stability related to land use categories assigning them a weighted score of ecological significance and a coeficient of antropogenic impact have been used to measure long-term land use changes. The cadastral territory of the municipality Rudñany was segmented by a regular grid of squares (with a real square size of 1 ha) to provide a uniform level of spatial detail and a comparison over time. Used grid method has shown that there was an increase in antopogenic impact on the landscape and the consequent reduction of its impact.
\end{abstract}

Keywords: landscape change processes, land use, antropogenic impact, ecological stability, environmental loads, Rudňany

\section{Úvod}

Ťažba nerastných surovín a opúšt’anie pol'nohospodárskej pôdy spôsobili rozsiahle zmeny využívania krajiny, ktoré sú typické pre kultúrnu krajinu Slovenského Rudohoria s dlhoročnou baníckou históriou a spracovávaním nerastných surovín. Kultúrnu krajinu, ktorá sa formovala v procese spájajúcom v sebe l'udské potreby s prírodnými zdrojmi a špecifické topografické vlastnosti s podmienkami životného prostredia. Zatial' čo niektoré l'udské aktivity zanechávajú v krajine len slabú odozvu, iné ostávajú viditel'né v priebehu stoviek rokov.

Zmeny krajiny vyjadrujú dynamickú interakciu medzi životným prostredím a socioekonomickými, ale aj kultúrnymi faktormi (Ramankutty a Foley, 1999; Antrop, 2005, Jakubcová a kol., 2016, Petrovič a Muchová, 2013, Michaeli a Boltižiar, 2010). Tieto zmeny významným spôsobom ovplyvňujú ekologickú stabilitu krajiny (Lipský, 2001), spôsobujú jej oslabenie a následne i pokles biodiverzity (Bezák a kol., 2016). Z týchto dôvodov sa $\mathrm{v}$ predmetnom článku zameriavame na preskúmanie intenzity l'udského vplyvu na vývoj využívania krajiny za posledných 190 rokov a jeho účinok na ekologickú stabilitu. 
Analýza dlhodobých zmien využívania krajiny a ich porovnávanie $\mathrm{s}$ predchádzajúcimi obdobiami napomáha $\mathrm{k}$ lepšiemu pochopeniu vzt’ahov medzi rozhodovacím procesom vo využívaní krajiny, jeho potenciálnym vplyvom a kvantifikáciou tohto vplyvu (Kanianska a kol., 2014, Kozová a kol., 2018, Kubinský a kol., 2015, Leitmanová, Bažík, Muchová, 2015, Lieskovský a kol., 2017, 2018, Majorošová a kol., 2018, Muchová, Jusková, 2017, Špulerová a kol., 2015, Munteanu a kol., 2017). Čoraz častejšie sa stretávame s prácami, ktoré sa zaoberajú dlhodobými zmenami využívania krajiny. Tento zvyšujúci sa trend monitorovania zmien využívania krajiny na základe dostupných historických mapových údajov sa stal široko používaním nielen na Slovensku (napr. Sul'ovský a kol., 2017) a v Českej republike (Havlíček a Chrudina, 2013, Opršal a kol., 2016), ale aj v iných európskych krajinách (Bender, 2005, Domaas, 2007, Peloross a kol., 2009).

\section{Teoreticko-metodické východiská}

Priestorová analýza zmien využívania krajiny bola realizovaná na mapách vytvorených metódou manuálnej vektorizácie plôšok. Ako podkladové vrstvy sme využili: historickú mapu z II. vojenského mapovania za rok 1822 v mierke 1:28 800 , vojenskú topografickú mapu s mapovaním v roku 1955 a v mierke 1:25 000 a farebnú leteckú ortofotosnímku z roku 2013 s rozlíšením rastra $0,5 \mathrm{~m}$ verifikovanú terénnym výskum uskutočnením v priebehu roka 2016. Základom pri príprave priestorových údajov $\mathrm{v}$ prostredí ArcGis 10.1 (C) ESRI) boli práce Mackovčin (2009), Skokanová (2009), Boltižiar a kol. (2016) a Muchová a Tárníková (2018). Výsledkom boli mapy využívania krajiny pri rešpektovaní minimálneho mapovaného areálu 0,8 ha. V mapách sme rozlišovali 6 kategórií využívania krajiny $(\mathrm{KVK})$ : orná pôda, lúky, pasienky, lesy, sídelná zástavba a ostatné plochy (bane a skládky odpadu).

Na posúdenie miery ekologickej stability sme využili metódu stanovania koeficientu ekologickej stability - KES podl’a Miklósa (1986), ktorý je založený na posúdení plošného zastúpenia stabilných a nestabilných KVK s prihliadnutím na ich ekologickú významnost'. Na základe výslednej numerickej hodnoty je krajina zaradená do určitého stupňa ekologickej stability (Petrovič, 2005). Koeficient má nasledovný tvar:

$$
\operatorname{KES}=\left(\frac{\sum_{\mathrm{i}=1}^{\mathrm{n}} \mathrm{p}_{\mathrm{i}} * \mathrm{k}_{\mathrm{p}_{\mathrm{i}}}}{\mathrm{p}}\right)
$$

kde $\mathrm{p}_{\mathrm{i}}$ je rozloha $\mathrm{i}$-tej formy využitia krajiny $\mathrm{v}$ analyzovanej priestorovej jednotke, $\mathrm{k}_{\mathrm{pi}}$ je koeficient ekologickej významnosti kategórie využitia krajiny (orná pôda $-0,14$; lúky - 0,62; pasienky - 0,68; lesy - 1,00; sídelná zástavba - 0,00; iné, napr.: bane a skládky odpadu - 0,14) a p je celková rozloha analyzovanej priestorovej jednotky. 
Následne sme hodnotili úroveň l'udského vplyvu na krajinu a jej vývoj vypočítaním koeficientu miery antropického ovplyvnenia krajiny - KAO (Kupková, 2001), ktorý predstavuje pomer plôch s vysokou intenzitou využitia krajiny (orná pôda, sídelná zástavba a ostatná plocha) a plôch s menšou intenzitou využitia krajiny (lúky, pasienky, lesy):

$$
\mathrm{KAO}=\frac{\left(\mathrm{r}_{\mathrm{OP}}+\mathrm{r}_{\mathrm{SZ}}+\mathrm{r}_{\mathrm{Osp}}\right)}{\left(\mathrm{r}_{\mathrm{L}}+\mathrm{r}_{\mathrm{p}}+\mathrm{r}_{\mathrm{Le}}+\mathrm{r}_{\mathrm{V}}\right)}
$$

kde $\mathrm{r}_{\mathrm{OP}}$ je rozloha ornej pôdy, $\mathrm{r}_{\mathrm{sz}}$ je rozloha sídelnej zástavby, $\mathrm{r}_{\mathrm{O} \text { P }}$ je rozloha ostatných plôch (napr.: bane, skládky odpadu), $\mathrm{r}_{\mathrm{L}}$ je rozloha lúk, $\mathrm{r}_{\mathrm{P}}$ je rozloha pasienkov, $r_{L e}$ je rozloha lesa a $r_{V}$ je rozloha vodných plôch. Rozloha sa vo všetkých prípadoch udáva v hektároch. Koeficient nadobúda hodnoty od 0 , horná hranica neexistuje. Hodnota 1 je dosiahnutá vtedy, ak je rozloha oboch typov plôch v rovnováhe. Hodnota vyššia ako 1 znamená, že prevažujú plochy s vysokou intenzitou antropického využitia.

Konečný výpočet KES a KAO sme realizovali v pravidelnej štvorcovej sieti o reálnej vel'kosti štvorca 1 ha $(100 \times 100 \mathrm{~m})$. Vel'kost' bola vybraná na základe prác Ivanová a kol. (2013), Muchová a Tárniková (2018). Výhoda tejto metódy spočíva veliminovaní nejednoznačných výsledkov, ktoré môžu vzniknút' pri plôškach, líšiacich sa navzájom vel'kost’ou a tvarom.

\section{Skúmané územie}

Katastrálne územie je v rámci geomorfologickej oblasti Slovenského Rudohoria situované do celku Volovské vrchy, podcelku Hnilecké vrchy a severné čast' do geomorfologickej časti Galmus (Mazúr a Lukniš, 1986). Geologické podložie je budované útvarmi staršieho a mladšieho paleozoika, mezozoika, terciéru a kvartéru. Útvary staršieho a mladšieho paleozoika sú bohaté na rudné žily, ktoré boli banícky využívané od stredoveku. Georeliéf je tvorený najmä erózno-denudačnými svahmi, z ktorých ojedinele vystupujú tvrdoše. K najzaujímavejším formám reliéfu patria zvyšky rozsiahlejšej krasovej planiny v severnej časti katastra. Územie je odvodňované Rudnianským potokom s dvoma väčšími l'avostrannými prítokmi do rieky Hornád. Z pôdnych typov majú najväčšie zastúpenie kambizeme, fluvizeme a v menšej miere rankre, rendzina a pararendziny (Krokusová a Čech, 2010). Aktuálna vegetácia je tvorená prevažne ihličnatými lesmi, ktoré boli počas t’ažby a spracovanie nerastov dlhé obdobie exploatované. $\mathrm{K}$ dominantnej drevine patrí smrek s prímesou borovice, smrekovca opadavého a miestami jedle (mapa 1). 
Mapa 1: Lokalizácia katastrálneho územia Rudňany v rámci a) kraja a b) okresu Map 1: Location of the cadastral area Rudňany within a) the region and b) the district

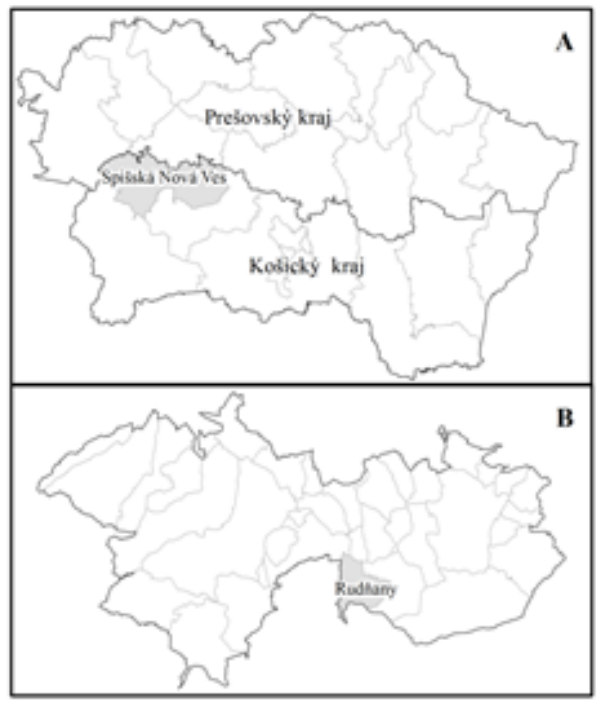

\section{Výsledky}

Pri spracovávaní druhotnej krajinnej štruktúry je potrebné rozlišovat' medzi súčasným a historickým využívaním krajiny. $\mathrm{V}$ našom prípade pozostávali mapy historického využívania krajiny z 20 plôšok (r. 1822), kde sme identifikovali 4 KVK a 46 plôšok (r. 1955), ktoré predstavovali 6 kategórií. Mapa zobrazujúca súčasné využívanie krajiny pozostávala zo 44 plôšok, v rámci ktorých sme identifikovali a zaznamenali $5 \mathrm{KVK}$.

Vo všetkých troch sledovaných rokoch (graf 1) zaberala kategória lesa najväčšiu rozlohu. V roku 1955 sa rozloha lesa znížila o 405,49 ha $(32,45 \%)$ na úkor ornej pôdy $(32 \%)$, pasienkov $(28 \%)$, lúk $(23 \%)$ a rozširujúcej sa sídelnej zástavby $(16 \%)$. Výrazné zmeny v rozložení a rozlohe KVK môžeme pozorovat' aj $\mathrm{v}$ roku 2013. Rozloha ornej pôdy klesla z pôvodných 131,56 ha v roku 1955 na nulu. K poklesu došlo aj v kategórii pasienkov o 81,98 ha a lúk o 59,7 ha. Tieto zmeny boli spôsobené najmä opúšt’aním pol’nohospodárskej pôdy, ktoré je úzko spojené so zalesňovaním. Najčastejšie sa tieto procesy vyskytujú v t’ažko dostupných, hornatých územiach, ktoré nie sú vhodné pre vel'koblokovú pol'nohospodársku produkciu (Skokanová a kol. 2016). Sídelná zástavba rástla napriek stavebnej uzávere vydanej v roku 1970 ako reakcia na nekontrolovanú exploatáciu a úpravu rúd, ale aj najväčšie znečistenie životného prostredia. 
Banskou činnost'ou sa vytvorilo rozsiahle závalové pásmo Baniská tiahnuce sa od jamy Mier po jamu Poráč. Bane a skládky odpadu zaberali najväčšie plochy v roku 2013. Konkrétne ide o haldu jamy Západ, haldu jamy 5RP II (čiastočne rekultivovaná), rekultivované smetisko a závaly postupne zavážané elektrárenským popolčekom (Krokusová a Čech, 2007). Prijatie utlmeného programu t’ažby a úpravy rúd a zrušenie stavebnej uzávery v roku 1995 vytvára predpoklady na revitalizáciu tohto bohatého baníckeho osídlenia.

Graf 1: Priestorová rozloha kategórií využívania kirajiny vyjadrená v hektároch (ha) za tri sledované časové horizonty

Graph 1: Area of land use categories in hectares for three time horizons

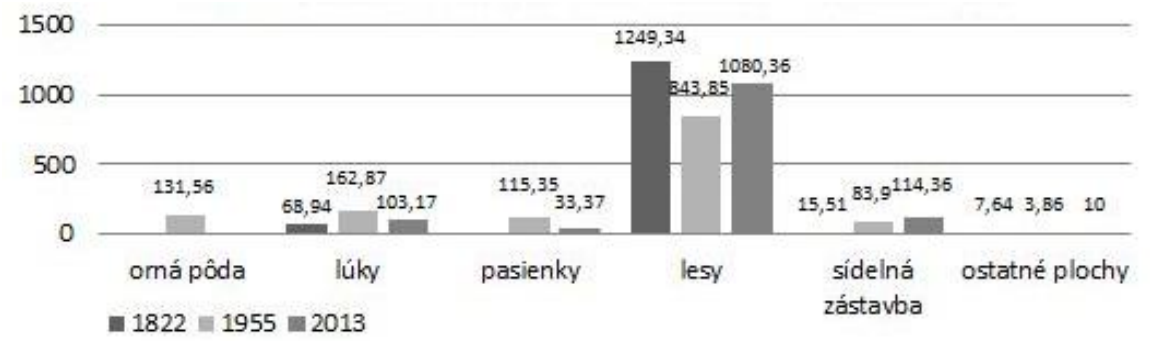

Prekrytím máp využitia krajiny pravidelnou štvorcovou siet'ou o vel'kosti štvorca 1 ha $(100 \times 100 \mathrm{~m})$ sme získali 1471 štvorcov. Z toho bolo 1217 úplných a 254 neúplných, nachádzajúcich sa po obvode skúmaného územia. Hodnotením KES v pravidelnej sieti štvorcov sme zistili (tab. 1), že za celé sledované obdobie došlo takmer vo všetkých intervaloch, s výnimkou najvyššieho intervalu - výrazne stabilizovaná krajina, k nárastu a následne k poklesu ich počtu. Medzi rokmi 1822 a 1955 sme pozorovali zmenu hodnoty KES až v 908 štvorcoch. V roku 1822 bola krajina výrazne stabilizovaná až v 1353 štvorcoch, čo bolo spôsobené značnou rozlohou kategórie lesa, ktorá zaberala 93,16\% územia. Dynamická schopnost' krajiny udržiavat podmienky svojej existencie súvisela so spracovávaním vyt’aženej rudy mimo územia katastra v Štefanskej Hute a Starej Vode. Rok 1955 sa vyznačoval viacerými zmenami. Dochádzalo k rozvoju obce a nárastu počtu obyvatel'ov. Vybudovaná bola triediareň a pražiareň známa pod menom Starý povrchový závod a železničné napojenie závodu na Markušovce. Všetky tieto zmeny sa odrazili v náraste počtu štvorcov v nižších intervaloch. Až o 148 štvorcov sa zvýšil interval výrazne nestabilizovanej krajiny, čo súviselo $\mathrm{s}$ rozširovaním sídelnej zástavby a objavením sa kategórii orná pôda a pasienky, zaberajúcich 18,41\% územia. Druhý výraznejší nárast o 207 štvorcov bol $\mathrm{v}$ intervale stabilizovanej krajiny, ktorý súvisel s rozšírením sa lúk na úkor lesa. V roku 2013 došlo k opätovnému poklesu počtu štvorcov v nižších intervaloch 
a nárastu v intervale výrazne stabilizovanej krajiny. Charakteristickými znakmi bolo vybudovanie Nového priemyselného závodu na úpravu rúd, dobudovanie mlynice a ortut'ovne a rozširovanie t’ažobných priestorov a s tým spojených háld, ktoré negatívne pôsobia na životné prostredie. Celkovo sme zaznamenali zlepšenie ekologickej stability krajiny, ktoré súviselo s prijatím útlmového programu t'ažby a úpravy rúd a protiemisnými opatreniami v roku 1995.

Tab. 1: Počet štvorcov a rozloha (ha) prislúchajúca vybranému intervalu koeficientu ekologickej stability

Table 1: Number of squares and area of individual ecological stability intervals

\begin{tabular}{|c|c|c|c|c|c|c|}
\hline \multirow{2}{*}{ KES } & \multicolumn{2}{|c|}{1822} & \multicolumn{2}{c|}{1955} & \multicolumn{2}{c|}{$\mathbf{2 0 1 3}$} \\
\cline { 2 - 7 } & štvorce & ha & štvorce & ha & štvorce & ha \\
\hline $\begin{array}{c}<0 ; \\
0,20>\end{array}$ & 5 & 4 & 153 & 145,01 & 78 & 75,13 \\
\hline $\begin{array}{c}0,20 ; \\
0,40>\end{array}$ & 3 & 3 & 61 & 59,73 & 35 & 33,34 \\
\hline $\begin{array}{c}0,40 ; \\
0,60>\end{array}$ & 29 & 29 & 70 & 63,85 & 43 & 39,38 \\
\hline $\begin{array}{c}0,60 ; \\
0 ; 80>\end{array}$ & 81 & 73,68 & 288 & 249,98 & 146 & 127,99 \\
\hline $\begin{array}{c}0,80 ; \\
1,00>\end{array}$ & 1353 & 1231,75 & 899 & 822,82 & 1168 & 1065,41 \\
\hline
\end{tabular}

Výpočtom KAO sme zistili, že v priebehu celého sledovaného obdobia dochádzalo $\mathrm{k}$ zvyšovaniu a následne znižovaniu antopogénneho vplyvu na krajinu. Tieto výsledky sa vo vel'kej miere zhodujú s výsledkami KES. Pri dôkladnejšom porovnávaní vytvorených máp ekologickej stability krajiny a antropického ovplyvnenia krajiny (mapa 2) môžeme sledovat' určité väzby medzi štvorcami s výraznou stabilitou krajiny a štvorcami s vysokou intenzitou využívania a opačne. Najnižšie hodnoty KAO (tab. 2) boli vypočítané vo štvorcoch s vysokým podielom stabilných plôch/nízkou intenzitou využívania (lúky, pasienky, lesy) a s nízkym až nulovým podielom nestabilných plôch/vysokou intenzitou využívania (orná pôda, sídelná zástavba a ostatná plocha). V tomto prípade šlo o 1460 štvorcov v roku 1822, čo predstavuje 99,21\% rozlohy územia, 1170 štvorcov v roku $1955(78,32 \%)$ a 1296 štvorcov v roku $2013(87,26 \%)$. Interval s hodnotou KAO väčšou ako 1,04 reprezentujúci vysokú intenzitu využívania bol v roku 1822 zastúpený 3 štvorcami. Celkovo sa najväčší antopogénny tlak prejavil v 202 štvorcoch $v$ roku 1955, čo predstavuje $14,8 \%$ územia a v 110 štvorcoch $v$ roku $2013(8,09 \%)$. Síce došlo k poklesu o 92 štvorcov pod vplyvom opustenia pol'nohospodárskej pôdy a jej postupného zalesňovania, ale t’ažba nerastných 
surovín a ich spracovanie sa výrazným spôsobom podpísali pod znečistenie životného prostredia. Pre čo najpresnejšie zachytenie rovnovážneho stavu vo štvorcoch bol zadefinovaný interval v rozmedzí 0,94 až 1,04 . Medzi sledovanými časovými horizontmi sa podiel týchto štvorcov postupne zvyšoval od $3 \mathrm{v}$ roku 1822 až k 6 v roku 2013.

Mapa 2: Koeficient ekologickej stability (vl'avo) a koeficient antropického ovplyvnenia krajiny (vpravo) vypočítaný v štvorcovej sieti (100 x $100 \mathrm{~m})$ Map 2: Coeficient of ecological stability (on the left) and coeficient of antropogenic impact (on the right) calculated by a regular grid of squares (100 x $100 \mathrm{~m})$

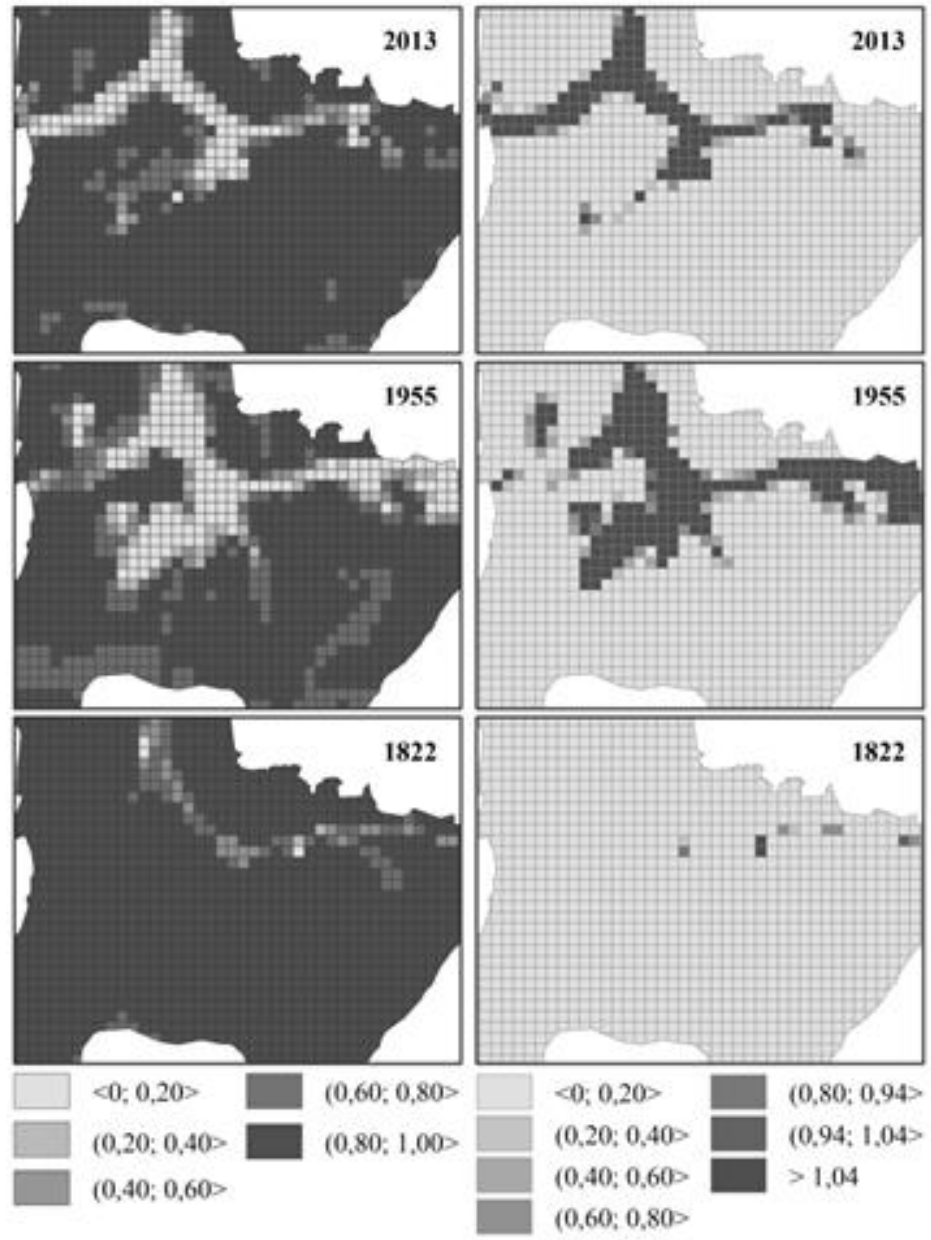


Tab. 2: Počet štvorcov a rozloha (ha) prislúchajúca vybranému intervalu koeficientu antropogénneho ovplyvnenia

Table 2: Number of squares and area of individual antropogenic impact intervals

\begin{tabular}{|c|c|c|c|c|c|c|}
\hline \multirow{2}{*}{ KAO } & \multicolumn{2}{|c|}{1822} & \multicolumn{2}{c|}{1955} & \multicolumn{2}{c|}{2013} \\
\cline { 2 - 7 } & štvorce & ha & štvorce & ha & štvorce & ha \\
\hline$<0 ; 0,20>$ & 1460 & 1330,43 & 1170 & 1050,38 & 1296 & 1170,15 \\
\hline $\begin{array}{c}(0,20 ; \\
0,40>\end{array}$ & 2 & 2 & 36 & 32,74 & 23 & 22,85 \\
\hline $\begin{array}{c}(0,40 ; \\
0,60>\end{array}$ & - & - & 31 & 29,74 & 15 & 13,9 \\
\hline $\begin{array}{c}(0,60 ; \\
0 ; 80>\end{array}$ & 4 & 4 & 22 & 21,07 & 14 & 13,92 \\
\hline $\begin{array}{c}(0,80 ; \\
0,94>\end{array}$ & 1 & 1 & 7 & 7 & 6 & 6 \\
\hline $\begin{array}{c}(0,94 ; \\
1,04>\end{array}$ & 1 & 1 & 2 & 2 & 6 & 6 \\
\hline$>1,04$ & 3 & 3 & 202 & 198,46 & 110 & 108,45 \\
\hline
\end{tabular}

\section{Diskusia}

Jednotlivé kategórie využívania krajiny/triedy krajinnej pokrývky (TKP) možno vnímat' ako biotopy alebo komplexy biotopov (Tallis et al., 2011) s rôznym stupňom hemeróbie, ktorá predstavuje mieru antropogénneho vplyvu na vegetáciu alebo celkový ekosystém. Podl'a Ot’ahel'a (2004) je pri hodnotení ekologickej stability krajiny dôležité poznanie krajinnej pokrývky, presnejšie jednotlivých TKP, ktoré umožňujú vyčlenit' podiel biotických zložiek a stanovit' ich ekologickú významnost'. Východiskom je detailná identifikácia a zaznamenávanie objektov zemského povrchu na základe ich morfoštruktúrnych a fyziognomických vlastností vo vel'kých mierkach. Z hl'adiska detailizovania krajinnej pokrývky patria medzi cenné práce Falt’an a Saksa (2004), Falt’an a kol. (2011), Druga a Falt’an (2014), Druga a kol. (2015) a Ot’ahel' a kol. (2017), ktoré prichádzajú s modifikáciou legendy Corine Land Cover a ucelenou legendou TKP na 5. hierarchickej úrovni. Určitou nevýhodou tejto metódy je identifikácie TKP len na základe súčasných a historických leteckých a satelitných snímok.

Ďalšou možnost’ou, ktorá by mohla priniest' uspokojivejšie výsledky pri hodnotení vplyvu človeka na krajinu a ekologickú stabilitu je využitie konceptu hemeróbie. V podstate je hemeróbia obrátenou hodnotou k stupňu prirodzenosti ekosystému, ak sú l’udské zásahy reverzibilné. Klasifikovanie kultúrnej krajiny na základe odchýlky od prirodzeného klimaxového štádia spôsobenej antopogénnym 
vplyvom nie je úplne novým nápadom. Svedčia o tom práce Jurko (1990), Walz a Stein (2014), Druga a Minár (2018). Ak by sme pri hodnotení ekologickej stability chceli využit' stupne hemeróbie, je potrebné spracovat' ich do podoby váženého skóre, ktoré by zohl'adňovalo stupeň ekologickej významnosti jednotlivých kategórii využívania krajiny/tried krajinnej pokrývky poskytujúcich biotopy rôznej kvality (Sowińska-Świerkosz, 2017).

Výsledky hodnotenia ekologickej stability krajiny a antropogénneho ovplyvnenia krajiny sa zhodujú s prácou Ot’ahel' a kol. (2004), ktorí hodnotili krajinnú štruktúru okresu Skalica a s prácami Ivanová a kol. (2013) a Michaeli a kol. (2015) zaoberajúce sa zázemím Zemplínskej Š́ravy. Síce v týchto prácach bolo hodnotenie realizované prostredníctvom TKP a koeficientu ekostabilizačnej schopnosti tried krajinnej pokrývky, ktorý vychádzal z myšlienky zastúpenia biotickej zložky v rámci identifikovaných tried, boli dosiahnuté rovnako vysoké hodnoty KES pre lesné a poloprírodné areály a areály $\mathrm{v}$ ich tesnej blízkosti. Zároveň sa potvrdilo, že štvorce s najvyšším stupňom ekologickej stability korešpondujú so štvorcami, v ktorých prevláda nízky stupeň využívania.

\section{Záver}

Aplikované metodické postupy nám umožnili jednoduchým spôsobom vyhodnotit' intenzitu l'udského vplyvu na krajinu a jej využívanie. Medzi hlavné zmeny využívania krajiny patrili urbanizácia, industrializácia (t’ažba a spracovanie rúd), pol’nohospodárska intenzifikácia, opúšt’anie pol'nohospodárskej pôdy a s tým úzke späté zalesňovanie. Tieto zmeny sa výrazným spôsobom podiel'ali na výsledných hodnotách ekologickej stability krajiny a jej priestorovom rozložení. Efektívnym nástrojom priestorovej analýzy ekologickej stability a antopogénneho vplyvu bola pravidelné siet' štvorcov, ktorá zabezpečila jednotnú úroveň podrobnosti a detailnosti. V priebehu sledovaného časového obdobia sme mohli pozorovat' znižovanie ekologickej stability, resp. zvyšovanie antropogénneho tlaku a následne zvyšovanie ekologickej stability, resp. znižovanie antopogénnho tlaku. Existujú však možnosti prepracovania používaných metód s ciel’om získania čo najpresnejších výsledkov o vlastnostiach druhotnej krajinnej štruktúry.

\section{Pod'akovanie}

Tento prispevok vznikol vd'aka podpore projektu VEGA 1/0496/16 a KEGA $032 U K F-4 / 2018$.

\section{Literatúra}

ANTROP, M. 2005. Why landscapes of the past are important for the future. In Landscape and Urban Planning. vol. 70, pp. 21-34. 
BENDER, O. - BOEHMERB, H. J. - JENS, D. - SCHUMACHER, K. P. 2005. Using GIS to analyse long-term cultural landscape change in Southern Germany. In Landscape and Urban Planning. vol. 70, pp. 111-125.

BEZÁK, P. - MITCHLEY, J. 2014. Drivers of change in mountain farming in Slovakia: from the socialist collectivisation to the Common Agricultural Policy. In Regional Environmental Change. vol. 14, pp. 1343-1356.

BOLTIŽIAR, M. - OLAH, B. - GALLAY, I. - GALLAYOVÁ Z. 2016. Transformation of the Slovak cultural landscape and its recent trends. In 17th International Symposium on Landscape Ecology - Landscape and Landscape Ecology. Location: Nitra, Slovakia, May 27-29, 2015. pp. 57-67.

DOMAAS, S. T. 2007. The reconstruction of past patterns of tilled fields from historical Cadastral Maps using GIS. In Landscape Research. vol. 32, pp. 23-43.

DRUGA, M. - FALŤAN, V. 2014. Influence of environmental drivers on the land cover structure and its long-term changes - case study of Malachov and Podkonice villages in Slovakia. In Moravian Geographical Reports. vol. 22, pp. 29-41.

DRUGA, M. - FALŤAN, V. - HERICHOVÁ, M. 2015. Návrh modifikácie metodiky CORINE Land Cover pre účely mapovania historických zmien krajinnej pokrývky na území Slovenska v mierke 1: 10000 - príkladová štúdia historického k. ú. Batizovce. In Geographia Cassoviensis. roč. 9, č.1, s. 17-34.

DRUGA, M. - MINÁR, J. 2018 Exposure to human influence - a geographical field approximating intensity of human influence on landscape structure. In Journal of Maps. vol. 14, no. 2, pp. 486-493.

FALŤAN, V. - BÁNOVSKÝ, M. - BLAŽEK, M. 2011. Evaluation of land cover changes after extraordinary windstorm by using the land cover metrics: a case study on the High Tatras foothill. In Geografie. vol. 116, no. 2, pp. 156-171.

FALŤAN, V. - SAKSA, M. 2007. Zmeny krajinnej pokrývky okolia Štrbského plesa po veternej kalamite v novembri 2004. In Geografický časopis. roč. 59, č. 4, s. 359-372.

HAVLÍČEK, M. - CHRUDINA, Z. 2013. Long-term land use changes in relation to selected relief characteristics in Western Carpathians and Western Pannonian basin - Case study from Hodonín District (Czech Republic). In Carpathian Journal of Earth and Environmental Sciences. vol. 8, pp. 231-244.

IVANOVÁ, M. - MICHAELI, E. - BOLTIŽIAR, M. - FAZEKAŠOVÁ, D. 2013. The analysis of changes ecological stability of landscape in the contrasting region of the mountain range and a lowland. In 13th International Multidisciplinary Scientific Geoconference SGEM 2013. Albena, Bulgaria., vol. 1, 2013. pp. 925-938.

JURKO, A. 1990. Ekologické s socioekonomické hodnotenie vegetácie. Bratislava: Príroda.

JAKUBCOVA, A. - GREŽO, H. - HREŠKOVÁ, A. - PETROVIČ, F. 2016. Impacts of Flooding on the Quality of Life in Rural Regions of Southern 
Slovakia. In Applied Research in Quality of Life. vol. 11, no. 1 pp. 221-237.

KANIANSKA, R. - KIREKOVÁ, M. - NOVÁČEK, J. - ZEMAN, M. 2014. Land-use and land-cover changes in rural areas during different political systems: A case study of Slovakia from 1782 to 2006. In Land Use Policy. vol. 36, pp. 554-566.

KOZOVÁ, M. - DOBŠINSKÁ, Z. - PAUDITŠOVÁ, E. - TOMČÁKOVÁ, I. RAKYTOVÁ, I. 2018. Network and participatory governance in urban forestry: An assessment of examples from selected Slovakian cities. In Forest Policy and Economics. vol. 89, pp. 31-41.

KROKUSOVÁ, J. - ČECH, V. 2007. Transformácia banskej krajiny na príklade obce Rudňany. In Zborník z konferencie Česká geografie v evropském prostoru. České Budejovice. 2007, s. 1105-1111. ISBN 978-80-7040-986-2.

KROKUSOVÁ, J. - ČECH, V. 2010 Selected aspects of transformation process and environmental conditions of mining villages after the stoppage of mining activities (on the example of Rudňany and Slovinky). In Globalization and crises in modern economy. Lithuania. ISBN 978-9955-18-507-9.

KUBINSKY, D. - WEIS, K. - FUSKA, J. - LEHOTSKÝ, M. - PETROVIČ, F. 2015. Changes in retention characteristics of 9 historical artificial water reservoirs near Banská Štiavnica. In Open Geosciences. vol 7, no. 1, pp. 1-8.

KUPKOVÁ, L. 2001. Data o krajině včera a dnes. In GEOinfo 1/2001, s. 16-19.

LEITMANOVÁ M. - BAŽÍK, J. - MUCHOVÁ, Z. 2015. New methods for gathering the spatial data from land consolidation project. In Acta Scientiarum Polomorum - Formatio Circumiectus. vol. 14, no. 1, pp. 125-133.

LIESKOVSKÝ, J. - LIESKOVSKÝ, T. - PISCOVÁ, V. 2017. Physical accessibility and its role in landscape developmentthree historical analyses from South Slovakia. In Landscape Research. vol. 42, no. 5, pp. 498-507.

LIESKOVSKÝ, J. - KAIM, D. - BALÁZS, P. - BOLTIŽIAR, M. - CHMIEL, M. - GRABSKA, E. - KIRÁLY, G. - KONKOLY-GYURÓ, E. - KOZAK, J. ANTALOVÁ, K. - KUCHMA, T. - MACKOVČIN, P. - MOJSES, M. MUNTEANU, C. - OSTAFIN, K. - OSTAPOWICZ, K. - SHANDRA, O. STYCH, P. - RADELOFF, V. C. 2018. Historical land use dataset of the Carpathian region (1819-1980). In Journal of Maps. vol. 14, no.2, pp. 644-651. MACKOVČIN, P. 2009. Land use categorization based on topographic maps. In Acta Pruhoniciana, vol. 91, pp. 5-13.

MAJOROŠOVÁ, M. - ŠTEFUNKOVÁ, Z. - BELČÁKOVÁ, I. - ŠKRINÁR, A. MACURA, V. 2018. The effect of gabions on the Quality of a stream habitat. In Applied Ecology and Environmental Research. vol. 16, no. 3, pp. 3461-3472. MAZÚR, E. - LUKNIŠ, M. 1986. Geomorfologické členenie SSR. 1:500 000. 1. vyd. Bratislava: Slovenská kartografia, 1986.

MICHAELI, E - BOLTIŽIAR, M. 2010. Selected Localities of Environmental Loads in the Slovak Republic. In Geographia Cassoviensis. vol. 4, no. 2, pp. 114-119. 
MICHAELI, E. - IVANOVÁ, M. - KOCO, S. 2015. The evaluation of anthropogenic impact on the ecological stability of landscape. In Journal of Environmental Biology. vol. 36, no. 1, pp. 1-7.

MIKLÓS, L. 1986. Stabilita krajiny v ekologickom genereli SSR. In Životné prostredie. roč. 20 , č. 2, s. 87-93.

MUCHOVÁ, Z. - JUSKOVÁ, K. 2017. Stakeholders' perception of defragmentation of new plots in a land consolidation project: Given the surprisingly different Slovak and Czech approaches. In Land Use Policy. vol. 66, pp. 356-363.

MUCHOVÁ, Z. - TÁRNÍKOVÁ, M. 2018. Land cover change and its influence on ecological risk assessment of the ecological stability. In Applied Ecology and Environmental Research. vol. 16, no. 3, pp. 2169-2182.

MUNTEANU, C. - KUEMMERLE, T. - BOLTIŽIAR, M. - LIESKOVSKY, J. MOJSES M. - KAIIM, D. - KONKOLY-GYURO, E. - MACKOVCIN, P. MÜLLER, D. - OSTAPOWICZ, K. - RADELOFF, V. C., 2017. Nineteenthcentury land-use legacies affect contemporary land abandonment in the Carpathians. In Regional Environmental Change. vol. 17, no. 8, pp. 2209-2222.

OPRŠAL, Z. - KLADIVO, P. - MACHAR, I. 2016. The role of selected biophysical factors in long-term land-use change of cultural landscape. In Applied Ecology and Environmental Research. vol. 14, pp. 23-40.

OŤAHEL', J. - FERANEC, J. - CEBECAUER, T. - PRAVDA, J. - HUSÁR, K. 2004. Krajinná štruktúra okresu Skalica: hodnotenie zmien, diverzity a stability. In Geographia Slovaca. vol. 19.

OŤAHEL', J. - FERANEC, J. - KOPECKÁ, M. - FALŤAN, V. 2017. Modifikácia metódy CORINE Land Cover pre identifikáciu a zaznamenávanie tried krajinnej pokrývky v mierke 1:10 000 na báze príkladových štúdií z územia Slovenska. In Geografický časopis. roč. 69, č. 3, s. 189-224.

PETROVIČ, F. 2005. Vývoj krajiny v oblasti štálového osídlenia Pohronského Inovca a Tribeča. Bratislava: ÚKE SAV, 2005. 209 s. ISBN 80-969272-3-X.

PETROVIČ, F. - MUCHOVÁ, Z. 2013. The potential of the landscape with dispersed settlement (case study Cadca town). In Public recreation and landscape protection - with man hand in hand. Brno 1.-3.5.2013. Brno: Mendlova univerzita, 2013. ISBN 978-80-7375-746-5, s. 199-204.

RAMANKUTTY, N. - FOLEY, J.A. 1999. Estimating historical changes in global land cover: croplands from 1700 to 1992. In Global Biogeochemical Cycles. vol. 13, pp. 997-1027.

SKOKANOVÁ, H. 2009. Application of methodological principles for assessment of land use changes trajectories and processes in South-Eastern Moravia for the period 1836-2006. In Acta Pruhoniciana. vol. 91, pp. 15-21.

SKOKANOVÁ, H. - FALŤAN, V. - HAVLÍČEK, M. 2016. Driving forces of main landscape change processes from past 200 years in Central Europedifferences between old democratic and post-socialist countries. In Ekológia (Bratislava). vol. 35, no. 1, pp. 50-65. 
SOWIŃSKA-ŚWIERKOSZ, B. 2017. Application of surrogate measures of ecological quality assessment: The introduction of the Indicator of Ecological Landscape Quality (IELQ). In Ecological Indicators. vol. 73, pp. 224-234.

SÚLOVSKÝ, M. - FALŤAN, V. - SKOKANOVÁ, H. - HAVLÍČEK, M. PETROVIČ, F. 2017. Spatial analysis of long-term land-use development in regard to physiotopes: case studies from the Carpathians. In Physical Geography. vol. 38, no. 5, pp. 470-488.

ŠPULEROVA, J. - PISCOVÁ, V. - GERHATOVÁ, K. - BAČA, A. KALIVODA, H. - KANHA, R. 2015. Orchards as traces of traditional agricultural landscape in Slovakia. In Agriculture Ecosystems \& Environment. vol. 199, pp. 67-76.

TALLIS, H. et al. 2011. InVEST 2.4.4 User's Guide. The Natural Capital Project, Stanford.

WALZ, U. - STEIN, C. 2014. Indicators of hemeroby for the monitoring of landscapes in Germany. In Journal for Nature Conservation. vol. 22, no. 3, pp. 279-289.

\section{EVALUATION OF THE INTENSITY OF ANTROPOGENIC IMPACT ON LAND USE AND ITS DEVELOPMENT: A CASE STUDY OF THE ENIRONMENTALLY-LOADED AREA RUDŇANY}

\section{Summary}

Exploitation of mineral resources and agricultural land abandonment have caused extensive land use changes that are characteristic for cultural landscape of Slovenské Rudohorie Mts with a long history of mining and mineral processing. Cultural landscape have been shaped over time, in an interactive process linking human needs with natural resources and features in a specific topographic and spatial setting. Whereas some human activities only left a short imprint on the scenery, others remain visible over thousands of years. Analysis of long-term landuse changes and their comparison with the recent period helps us to understand the links between land use choices, their potential impact and the quantification of this impact. Changes in landscape structure have a significant effect on ecological stability, as well as contemporary biodiversity decline. Therefore, this artical investigates the impact of human activities on the long-term land-use development over the last 190 years and its influence on ecological landscape stability.

Land-use changes of study area were analyzed using land-use maps created by on-screen digitization on the basis of old topographic maps and aerial photograph in the ESRI ArcGIS environment. As underlying layers were used: map from the $2^{\text {nd }}$ Austro-Hungarian Military Survey in the scale 1:28 800 (1822), the Czechoslovak military topographic map in a scale 1:25 000 (1955) and aerial photograph with the raster resolution of 0.5 meters (years 2005 and 2009). Maps 
distinguished six land-use categories: arable land, permanent grassland, pastures, forest, build-up area, other area (e. g. mine and dump sites). This method set relatively homogenous land-use spatial units at minima of 0.8 ha area. A coefficient of ecological stability (Miklós, 1986) related to land use categories assigning them a weighted score of ecological significance and a coeficient of antropogenic impact (Kupková, 2001) have been calculated. In addition to this, the study area was segmented by regular grid cells that were used as a means of spatial reference. While the land area of municipalities varies in size, and thus the calculated coefficients must always be considered as values relative to this area, the use of grid cell avoids the ambiguity of results based on different reference units. Moreover, the map representation provides a uniform level of detail.

Degrees of ecological stability (e.g. Petrovič, 2005) and intensity of antropogenic impact on landscape were distinguished by overlaying land-use maps with a regular $100 \times 100 \mathrm{~m}$ grid cells. The results showed that ecologically negative changes clearly dominate in the 1955. Urbanization, industrialization, agricultural intensification, agricultural land abandonment (closely linked with afforestation via natural vegetation succession as well as artificial afforestation in areas) belong to the main changes in land use.

\section{Mgr. Matej Hruška}

Katedra fyzickej geografie a geoekológie

Prírodovedecká fakulta

Univerzita Komenského v Bratislave

Ilkovičova 6, 84215 Bratislava

E-mail: hruska35@uniba.sk

\section{prof. RNDr. František Petrovič, PhD.}

Katedra ekológie a environmentalistiky

Fakulty prírodných vied

Univerzita Konštantína Filozofa v Nitre

Tr. A. Hlinku 1, 94974 Nitra

E-mail: fpetrovic@ukf.sk 